\title{
Open-chest versus closed-chest cardiopulmonary resuscitation in trauma patients: effect size is probably higher for penetrating injury
}

\author{
Romain Jouffroy ${ }^{1,2}$ (D) and Benoit Vivien ${ }^{2^{*}}$
}

To the Editor,

Endo et al. [1] recently reported that compared to closedchest cardiopulmonary resuscitation (CCCPR), openchest cardiopulmonary resuscitation (OCCPR) was associated with significantly higher survival at hospital discharge in severe trauma patients with signs of life upon emergency department arrival.

The authors should be congratulated for their very interesting study in the utmost important field of traumatic cardiac arrest. Nevertheless, we believe that some points of their study should be pointed out.

Endo et al. used a propensity score matching analysis to mimic a randomized control trial, and the readers should be aware that this methodology reduces the differences according to the type of injury. Indeed, international guidelines for cardiopulmonary resuscitation (CPR) recommend, beyond symptomatic CPR, the etiological treatment of reversible causes of cardiac arrest, which are summarized by the $4 \mathrm{H}$ and $4 \mathrm{~T}$ mnemonic tool (i.e., hypovolemia, hypoxemia, hypo/hyperkalemia, hypothermia, toxic, tamponade, pneumothorax, and pulmonary/coronary thrombosis) [2, 3]. However, propensity score matching reduces the differences between blunt and penetrating injury groups, for whom cardiac arrest

\footnotetext{
${ }^{*}$ Correspondence: benoit.vivien@aphp.fr

${ }^{2}$ SAMU de Paris, Service d'Anesthésie-Réanimation, Hôpital Universitaire Necker - Enfants Malades, APHP, Centre, Assistance Publique - Hôpitaux de Paris, and Université de Paris, Paris, France

Full list of author information is available at the end of the article
}

etiological treatment present major differences. First, penetrating injuries result in a higher cardiac arrest proportion requiring an open-chest intervention that may fully explain the relative weight of the variable, "number of trauma surgeons in a hospital," on outcomes observed in Endo et al. study [1]. Second, blunt trauma patients generally present multiple injuries, many of which include brain trauma, which could dramatically impair prognosis whenever any injury occurs that is accessible to treatment by OCCPR. Finally, the propensity score matching does not include two major cardiac arrest outcome determinants: the no-flow and the low-flow durations $[4,5]$.

Beyond these considerations, we agree with Endo et al. [1], that the use of OCCPR should be considered more frequently for trauma patients presenting with cardiac arrest upon hospital arrival, especially those with penetrating injury.

\section{Acknowledgements \\ None.}

Authors' contributions

BV and RJ wrote the manuscript. Both authors read and approved the final manuscript.

Funding

None.

Availability of data and materials

Not applicable.

Ethics approval and consent to participate Not applicable.

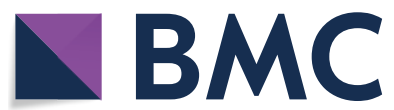

(c) The Author(s) 2020. Open Access This article is licensed under a Creative Commons Attribution 4.0 International License, which permits use, sharing, adaptation, distribution and reproduction in any medium or format, as long as you give appropriate credit to the original author(s) and the source, provide a link to the Creative Commons licence, and indicate if changes were made. The images or other third party material in this article are included in the article's Creative Commons licence, unless indicated otherwise in a credit line to the material. If material is not included in the article's Creative Commons licence and your intended use is not permitted by statutory regulation or exceeds the permitted use, you will need to obtain permission directly from the copyright holder. To view a copy of this licence, visit http://creativecommons.org/licenses/by/4.0/. The Creative Commons Public Domain Dedication waiver (http://creativeco mmons.org/publicdomain/zero/1.0/) applies to the data made available in this article, unless otherwise stated in a credit line to the data. 


\section{Consent for publication}

Not applicable.

\section{Competing interests}

The authors declare that they have no competing interests.

\section{Author details}

${ }^{1}$ Intensive Care Unit, Ambroise Paré Hospital, Assistance Publique - Hôpitaux de Paris, Boulogne-Billancourt, France. ${ }^{2}$ SAMU de Paris, Service d'Anesthésie-Réanimation, Hôpital Universitaire Necker - Enfants Malades, APHP, Centre, Assistance Publique - Hôpitaux de Paris, and Université de Paris, Paris, France.

Received: 19 October 2020 Accepted: 4 November 2020

Published online: 23 November 2020

\section{References}

1. Endo A, Kojima M, Hong ZJ, Otomo Y, Coimbra R. Open-chest versus closed-chest cardiopulmonary resuscitation in trauma patients with signs of life upon hospital arrival: a retrospective multicenter study. Crit Care. 2020;24(1):541.
2. Panchal AR, Berg KM, Hirsch KG, Kudenchuk PJ, Del Rios M, Cabanas JG, et al. 2019 American Heart Association focused update on advanced cardiovascular life support: use of advanced airways, vasopressors, and extracorporeal cardiopulmonary resuscitation during cardiac arrest: an update to the American Heart Association guidelines for cardiopulmonary resuscitation and emergency cardiovascular care. Circulation. 2019;140(24):e881-94.

3. Perkins GD, Olasveengen TM, Maconochie I, Soar J, Wyllie J, Greif R, European Resuscitation Council, et al. update. Resuscitation. 2017;2018(123):43-50.

4. Adnet F, Triba MN, Borron SW, Lapostolle F, Hubert H, Gueugniaud PY, et al. Cardiopulmonary resuscitation duration and survival in out-ofhospital cardiac arrest patients. Resuscitation. 2017;111:74-81.

5. Jouffroy R, Vivien B. Prognostic value of venous blood analysis at the start of CPR in non-traumatic out-of-hospital cardiac arrest: association with ROSC and the neurological outcome: do not forget the no-flow influence! Crit Care. 2020;24(1):232

\section{Publisher's Note}

Springer Nature remains neutral with regard to jurisdictional claims in published maps and institutional affiliations.
Ready to submit your research? Choose BMC and benefit from:

- fast, convenient online submission

- thorough peer review by experienced researchers in your field

- rapid publication on acceptance

- support for research data, including large and complex data types

- gold Open Access which fosters wider collaboration and increased citations

- maximum visibility for your research: over $100 \mathrm{M}$ website views per year

At BMC, research is always in progress.

Learn more biomedcentral.com/submissions 